\title{
Steam and Water Distillation of Piper Betle, Ocimum Basilicum, Cymbopogon Winterianus, and Citrus Hystrix Leaves for Activity of Insect Repellent against Mosquito
}

\author{
Engrid Juni Astuti *, Sovia Aprina Basuki, Aris Sabrian, and Ferawati Fajriyah \\ Departement of Pharmacy, Faculty of Health Science, University of Muhammadiyah Malang, \\ Indonesia \\ Jl. Bendungan Sutami 188A, Kota Malang, Jawa Timur, 65145 \\ *Corresponding author: engridjuni81@gmail.com
}

\begin{abstract}
Background : Piper betle, Ocimum basilicum, Cymbopogon winterianus, and Citrus hystrix leaves contain essential oils suspected of having mosquito repellent activity, which can be used as a synthetic repellent alternative such as DEET. Objective: To obtain insect natural repellent to mosquitoes from essential oils. Method: Steam and water distillate to obtain essential oils, GC-MS to know its chemical content. The insect repellent volatile oil activity test in various combinations of concentrations against Aedes aegypti mosquitoes used the subject of mice for 6 hours. Result: Steam and water distillates yielded oils with $0.56 \% \mathrm{v} / \mathrm{b}$ (Piper betle), $0.33 \%$ v / b (Ocimum basilicum), $1.7025 \%$ (Cymbopogon winterianus) and $0.693 \%$ (Citrus hystrix). The yield of GC-MS Piper betle leaf oil contains Chavicol acetate compounds (19.284\%) and Trans-isoeugenol (18.485\%), Ocimum basilicum leaf oil contains z-citral compounds (54.201\%), Cymbopogon winterianus leaf oil contain citronellal oil (35.843\%), and Citrus hystrix leaf oil contain Citronellal (66,550\%). The results of the activity test showed that the combination of Piper betle and Ocimum basilicum leaves oils had insect repellent activity which was not different with DEET 13\%, except for the lower concentration of 50:50. While the combination of Cymbopogon winterianus and Citrus hystrix leaves oils showed that there was a difference of protection between treatment groups, and there was a difference of protection at test time interval because $p$ value <0,05. Conclusion: Piper betle and Ocimum basilicum leaves oils or combination of both and Cymbopogon winterianus and Citrus hystrix leaves oils or combination of both potentially as an alternative insect natural repellent to mosquitoes.
\end{abstract}

Keywords: Piper Betle, Ocimum Basilicum, Cymbopogon Winterianus, Citrus Hystrix Leaves, Steam And Water Distillate, Insect Repellent, Mosquitoes.

\section{INTRODUCTION}

Plants are able to make metabolite from the metabolism in their body. The metabolites are divided into two, namely primary metabolites and secondary metabolites (Kabera et al. 2014; Tiwaru \& Rana 2015). Secondary metabolites can be contained in volatile components called essential oils. This oil has many benefits for humans, so to obtain it can be used various methods of extraction, such as distillation, supercritical extraction of carbon dioxide, and extraction using certain solvents (Christaki et al. 2012; Wink 2015). The developed method of distillation has three types: water distillation, steam and water distillation, and 
steam distillation. In this research, steam and water distillation methods are used, where the materials and water are separated by a perforated filter in one kettle. This method was chosen because it has advantages than water distillation, such as materials was distilled not burnt, better oil quality, and higher oil yield (Guenther 1987). Compounds such as eugenol, limonene, terpinolene, citronellal, and camphor contained in volatile oils indicate rejection activity in mosquitoes and other biting insects, which can be used as an alternative mosquito repellent replace synthetic chemicals (Christaki et al. 2012; Kalita et al. 2013).

Insect repellent can be divided into three categories: physical, synthetic, and natural repellent. Of the 3 categories, synthetic repellent with chemical ingredients such as DEET is the most proven repellent to prevent insect bites, but on the other hand can harm human health (Katsambas et al. 2015). For that, the use of natural repellent from essential oils of plants can be used as an alternative that is considered more secure. The volatile essential oil works by blocking the odor receptors on the insects so that it can not smell the host target normally (Maia \& Moore 2011).

In the previous research the essential oils of betel plants contain phenol group compounds such as safrol and eugenol which have insect repellent and insecticidal activity (Mohottalage et al. 2007; Mahesh \& Chandrashekar 2010). While the essential oils of the Ocimum genus include $O$. basilicum contains components such as sitral, eugenol and linalool that have rejection activity against for some types of mosquitoes (Maia \& Moore 2011). The main components essential oil of citronella leaves are citronellal (32-45\%), citronellol (11$15 \%$ ), and geraniol (12-18\%) (Sastrohamidjoho 2004). Based on previous research, essential oil of citronella leaves has activity as insect repellent (Rani et al. 2013). While the main components of essential oil of citrus leaves are citronellal, linalool, citronelol. Citrus leaves oil has effectiveness as biolarvaside to instar III Aedes aegypti mosquito (Istianah \& Ameliana 2013).

In this experiment, extraction essential oil from betel leaves (Piper betle), basil leaves (Ocimum basilicum), citronella leaves (Cymbopogon winterianus) and citrus leaves (Citrus hystrix) by steam and water distillation method to be tested both single and combination essential oil of betel leaves with basil leaves and citronella leaves with citrus leaves as insect repellent to mosquito.

\section{METHOD}

Material: betel leaves, basil leaves, citronella leaves, citrus leaves, aquadest (water), $\mathrm{NaCl}$, anhydrous sodium sulphate, adult female Aedes aegypti mosquitoes, dessicated powdered beef liver, 5\% sugar solution (honey), rat test subjects (Rattus norvegicus) female Wistar strains with uniform age and weight, aquadest, topical antimosquito products (Soffel spray) as positive control, ethanol, sudan III reagent, and acetone.

Equipment: distillation, filter, condenser, bunsen, separating funnel, erlenmeyer, measuring glass, analytical scales, refrigerator, pycnometer, refractometer, Gas Chromatography-Mass Spectrometry (GC-MS), dropper, injection syringes, stirring rods, dark glass vials, shaver, aluminum foil, filter paper, $40 \mathrm{~cm} \times 40 \mathrm{~cm} \times 40 \mathrm{~cm}$ mosquito cage, aspirator, and mouse cage.

Distillation of Leaf Essential Oils: The method of distillation applied in this study is based on the method (Guenther 1987; Nurhidayati et al. 2012). The leaves are washed and then dried at room temperature for \pm 2 days, chopped and weighed. Used each $\pm 3.5 \mathrm{~kg}$ of leaves that have withered. Leaves are distilled separately. The distillation process is carried out for 2 - 3 hours or until the essential oil does not drip anymore marked by a clear destilat. The stored destilate is then added with $\mathrm{NaCl}$ to allow the emulsified oil to separate and the water phase to become clear. Water phase and oil phase separated by separating funnel. The oil phase is added anhydrous sodium sulfate, wait for a moment, then decanted. The volatile oil 
of the decantation is measured in volume, then inserted in an airtight dark vial, and stored in the freezer until the activity test period.

Preliminary Essential Oil Test: The preliminary test is performed by looking at the yield of the volatile oil produced from the distillation process, the organoleptis of each essential oil, the identification of essential oils used the reagent of Sudan III (DEPKES RI 1979; Ekowati et al. 2013), the determination of density used picnometer, the determination of refractive index used refractometer, solubility determination in ethanol $90 \%$ or $96 \%$, and chemical characterization of essential oils used Gas Chromatography-Mass Spectrometry (GC-MS)

Insect Repellent Activity Test: The activity test of essential oil of betel leaves, basil leaves, citronella leaves and citrus leaves as insect repellent to mosquito was done through several stages, which are described as follows:

a. Rearing Mosquitoes: Mosquito eggs obtained from the East Java Provincial Health Office are placed in plastic containers containing $3 / 4$ water. After the eggs hatch into larvae, it is moved in a container of fresh water and put in a mosquito cage until it turns into an adult mosquito. In the larvae phase fed (dessicated, powdered beef liver). An adult mosquito is fed only $5 \%$ sugar solution until the test time will be carried out. The female mosquito samples were taken from the entire mosquito population using aspirator and transferred into a test cage, 3 to 7 days old. The sample mosquitoes are fasted 12 hours before testing (Medikanto et al. 2013).

b. Positive Control Solution : Positive control used topical anti-mosquito product (Soffel spray) containing DEET $13 \%$ and has proven efficacy and has been marketed in Indonesia $(\mathrm{K}+)$.

c. Negative Control Solution : The negative controls in this study did not use any ingredients applied to the skin (K-).

d. Preparation of Test Solution: Testing using essential oil of betel leaves, basil leaves, citronella leaves, and citrus leaves with different concentration as much as $1.5 \mathrm{ml}$ for 3 replication, measurement of oil volume using scaled injection syringe. Explained as follows:

Table 1. Formula Combination of Essential Oil

\begin{tabular}{|c|c|c|c|c|c|}
\hline Formula & $\begin{array}{l}\text { Betel leaves oil } \\
(\mathrm{ml})\end{array}$ & $\begin{array}{l}\text { Basil leaves oil } \\
\text { (ml) }\end{array}$ & Formula & $\begin{array}{c}\text { Citronella } \\
\text { leaves oil }(\mathrm{ml})\end{array}$ & $\begin{array}{l}\text { Citrus leaves } \\
\text { oil (ml) }\end{array}$ \\
\hline 1 & 1,5 & - & 6 & 1,5 & - \\
\hline 2 & 1,05 & 0,45 & 7 & 1,05 & 0,45 \\
\hline 3 & 0,75 & 0,75 & 8 & 0,75 & 0,75 \\
\hline 4 & 0,45 & 1,05 & 9 & 0,45 & 1,05 \\
\hline 5 & - & 1,5 & 10 & - & 1,5 \\
\hline
\end{tabular}

e. Procedures Insect Repellent Test Activity : Used test subjects as animals, ie rats (Rattus norvegicus) as much as 7 rats each replication. Every single rat is used for one treatment. Used the back skin rat of a $5 \mathrm{~cm} \times 5 \mathrm{~cm}$ that has been shaved for testing. Shaved hair so that test solution applied can be attached directly to the skin of the rat. Each mouse was smeared with 1 test solution of $0.5 \mathrm{ml}$ each. Then each mouse was inserted into a different test cage containing 50 female Aedes aegypti mosquitoes. The test was performed for 6 hours, in which the rat was put into the test cage for 5 minutes at the beginning of each hour. The number of mosquitoes that settled for a period of 5 minutes on the rats' back was recorded. Tests for each treatment were replicated 3 times on different days. During the test it is attempted that environmental factors are maintained as room temperature is maintained at $27^{\circ} \pm 2^{\circ} \mathrm{C}$, relative humidity ranges from $\geq 80 \pm 10 \%$, and fotoperiode $12: 12$ (light: dark)

Calculation \% Protection Power : The percentage of protection power of each test material is determined as the proportion of the number of mosquitoes perched on the rats' backs 
smeared with test solution with the number of mosquitoes perched on the back of the control rat, the formula of calculation is as follows:

Information :

$$
\mathrm{DP}=\frac{\mathrm{K}-\mathrm{P}}{\mathrm{K}} \times 100 \%
$$

$\mathrm{DP}=$ Protection Power $(\%)$

$\mathrm{K}=$ number of mosquitoes settling on negative control rats

$\mathrm{P}=$ number of mosquitoes settling on treatment / control $(+)$ rats

Statistical Analysis : Statistical analysis was used to determine the significant differences in protection power between treatment groups (positive control, negative control and test group) for six hours with three replications. The statistical test used was a two-way ANOVA analysis, with two independent variables: treatment group and time interval (hour). Determination of the difference of protection power with two variables is done with the level of significance $(\alpha)$ of $5 \%$. If there is a difference between the groups $(\mathrm{p}<0.05)$, then the Post Hoc test is the Tukey HSD test (Honestly Significant Difference) done to determine which group is different.

\section{RESULTS AND DISCUSSION}

This research begins by distillation of steam and water from betel leaves (Piper betle), basil (Ocimum basilicum), citronella leaves (Cymbopogon winterianus) and citrus leaves (Citrus hystrix) which was previously air-dried for \pm 2 days at room temperature until wilted which aims to reduce water content in the material so that the essential oil yield is increased (Tutik et al. 2010). Distillation of these plant materials is done separately. The wilted leaves are then shredded into small pieces so that the oil glands on the leaves can open as much as possible, so that the diffusion process of essential oil gets easier and the faster rate of oil evaporation. The ready material is then distilled for 2-3 hours, using 3 liters of water per distillation. Steam and water distillation allows distilled materials to be associated only with steam and not with hot water, so the risk of oil decomposition is smaller (ester hydrolysis, polymerization, resinification, etc.) (Guenther 1987). The results showed that the yield of essential oil obtained from steam and water distillation betel leaves was $0.56 \% \mathrm{v} / \mathrm{b}$, basil leaves by $0.33 \% \mathrm{v} / \mathrm{b}$, citronella leaves $1.7025 \%$, while citrus leaf oil produces $0.693 \%$.

The next process of this research was the characterization of essential oils, the purpose was to know the purity of the essential oils produced. The first was the essential oil organoleptis of both plant material which results according to the description of essential oils in Pharmacopoeia Indonesia third edition (DEPKES RI 1979), ie clear liquid with aroma such as the aroma of the original plant. test characterization of volatile oil of betel leaves in the form of clear liquid, clear yellow color, flavored betel leaf. In the essential oil of basil leaves showed organoleptis in the form of clear liquid, yellow, basil leafy aroma. In the essential oil of citronella leaves showed organoleptis form clear liquid and citronella odour. While the essential oil of citrus leaves showed organoleptis form clear liquid and citrus odour. Identification was generally standardized.

Determine density of essential oil used piknometer. The density was the ratio of the weight of oil to the water weight at the same volume and temperature, where the density for the betel leaves oil was 0.990 , essential oil of basil leaves of 0.899 , citronella leaveas oil of 0.8844 , and essential oil of citrus leaves of 0.8463 . The density of the essential oil is smaller than water $(1,000)$, thus causing the essential oil position to be above the water if both substances are mixed. The density is influenced by the components that make up the essential oil, when composed by many components with large molecular weight, the density of oil will also be high. The duration of the distillation process can also have an effect, which at the 
beginning of the process will result in an oil fraction that is lighter than water, then gradually resulting in a heavier oil fraction, so that density of the oil will increase (Guenther 1987; Yuliarto et al. 2012).

Determination of refractive index used refractometer. The refractive index is the ratio of the incident angular sinus to the reflected ray sinus, if light passes through less dense media to a denser medium, then the ray will bias than the normal line (Guenther 1987). The refractive index is affected by components that make up volatile oils, eg components having long carbon chains and there are a number of double bonds will increase the refractive index value, and still the water content in the oil can decrease the refractive index value due to the easy nature of refracting light (Tutik et al. 2010; Yuliarto et al. 2012). The refractive index for essential oils produced is 1.5126 (betel), 1.4890 (basil), 1.4696 (citronella) and 1.4526 (citrus).

The solubility of essential oils in ethanol $90 \%$ and $96 \%$. The essential oil of betel leaves has a solubility of 1: 0.3 in 96\% ethanol and 1: 1 in ethanol 90\%, which means 1 part (ml) of essential oil dissolved in 0.3 parts $(\mathrm{ml})$ of ethanol 96\%, whereas 1 (ml) essential oil can dissolve in 1 part ( $\mathrm{ml}$ ) ethanol $90 \%$. In the essential oil of basil leaves its solubility was 1 : 0.8 on ethanol $96 \%$ and 1: 6 on ethanol $90 \%$. In the essential oil of citronella leaves its solubility in ethanol $96 \%$ was 1: 1 while the essential oil of citrus leaves of solubility in ethanol $96 \%$ was 1: 0,5. From the results of this test it can be seen that the non-polar component of both essential oils is more because it is more soluble in ethanol $96 \%$ than $90 \%$ ethanol. The solubility is affected by the components contained, in which the oxygenated components such as alcohols, aldehydes, ketones and phenols are more soluble in alcohol (ethanol) than terpen (not oxygenated). The compounds of esters and phenols have a smaller solubility, whereas paraffin and sesquiterpene are not soluble in alcohol (Yuliarto et al. 2012).

The last characterization was to analyze the chemical composition of each essential oil used Gas Chromatography-Mass Spectrometry. At betel leaves volatile oil found 32 chemical compounds, with the largest percentage of Chavicol acetate (19.284\%), followed by Transisoeugenol (18.485\%), Acetyl eugenol (18.370\%), and 4-allyl-1,2-diacetoxybenzene $(12.564 \%)$. The compounds are a class of organic compounds of phenylpropanoid or phenol. The compound analyzed in this study differed somewhat from previous studies in which the largest component of eugenol (36.2\%), followed by chavibetol acetate (16.9\%), 4-allylphenyl acetate/chavicol acetate (9.4\%) and 4-allylphenol (7.2\%) (Rekha et al. 2014). In the composition of essential oil of basil leaves was found 31 compounds, with the largest percentage of z-citral of $54.201 \%$, this compound was detected at 2 different retention time of 13.899 minutes and 14.549 minutes. Other compounds with a large percentage of Cis- $\alpha-$ bisabolene $(7.075 \%), \quad \beta$-caryophyllene $(6.544 \%)$, and Germacrene D $(4.707 \%)$. The compounds are terpenoid group compounds, in which z-citral or neral are monoterpenes, whereas Cis- $\alpha$-bisabolene, $\beta$-caryophyllene, and Germacrene D are sesquiterpenes. The compound components analyzed in this study differed somewhat from previous studies in which the largest component of essential oils of basil leaves were Z-Citral (45.53\%), E-Citral (45.57\%), linalool (3.64\%), $\alpha$-relamot $(1.59 \%)$, trans-caryophyllene $(1.34 \%)$ (Fajarini \& Murrukmihadi 2015). The results of gas-spectrometry chromatography both citronella leaves oil and citrus leaves oil have the same main chemical compound, Citronellal, but at different levels of $35.843 \%$ (citronella leaves oil) and $66.550 \%$ (citrus leaves oil). The difference in chemical components and the percentage of each study can be due to the environmental conditions in which the plant lives, given that the essential oil content is a secondary metabolite used to adapt to its environment (Mohottalage et al. 2007; Tiwari \& Rana 2015). Of the compounds present in the essential oil of betel leaves, it is suspected that organic phenolic group compounds (such as eugenol and its derivatives, and isosafrole-although its 
content is only $0.113 \%$ ) have the potential to repel insects (Mohottalage et al. 2007; Mahesh \& Chandrashekar 2010; Singh 2014). While the z-citral compounds $(54.201 \%)$, $\beta$ caryophyllene $(6.544 \%)$, linalool $(1,610 \%)$ and p-eugenol $(0.168 \%)$ in volatile oils of basil leaves have the potential to repel mosquitoes. The other compounds contained in the volatile oil from this study which have potential as mosquito repellent include L- $\alpha$-pinene, 4terpineol, $\beta$-myrcene, $\alpha$-terpinene, eucalyptol, $\alpha$-terpineol, and citronella which are the largest compounds in essential oil citronella leaves and citrus leaves (Maia \& Moore 2011).

Testing of essential oil activity obtained from steam and water distillation as insect repellent against mosquito for 6 hours. This study used the test subjects of mouse (Rattus novergicus) which shaved the back of $5 \mathrm{~cm} \times 5 \mathrm{~cm}$ wide for tested material. While the research sample was Aedes aegypti female mosquito adult as much as 50 rat each treatment. The treatment group consisted of positive control (soffel spray DEET 13\%), negative control (without any treatment), while the test group consisted of mixture of betel leaves oil and basil leaves oil in 5 concentrations and mixture of essential oil of citronella leaves and citrus leaves in 5 concentrations. The results of statistical activity test using two-way variance analysis showed that the essential oil of betel leaves and basil leaves at various concentration combinations had insect repellent activity against Aedes aegypti mosquito for 6 hours. Its effectiveness is the same as DEET 13\%, except the essential oil at concentration 50:50 with lower effectiveness. While the results of two way anova obtained on the combination of essential oil of citronella leaves and citrus leaves showed that there was a difference of protection power between treatment groups. In addition, in two way anova also shows that there is difference of protection power at test time interval that is at hours $0,1,2,3,4,5$, and 6 . However, at the time interval of the $0^{\text {th }}$ hour test with the $1^{\text {st }}$ hour, the $0^{\text {th }}$ hour with the $2^{\text {nd }}$ hour, the $1^{\text {st }}$ hour with the $2^{\text {nd }}$ hour, and the $2^{\text {nd }}$ hour with the $3^{\text {rd }}$ hour there is no difference power protection ( $p>0.05)$. The volatile components of the volatile oil may interfere with the Olfactory Receptor Neuron mosquito response to attractant (lactic acid and carbon dioxide) produced by a host such as humans or animals, so that the mosquito is unable to detect the presence of the host (Debboun et al. 2015).

\section{CONCLUSION}

From the research results obtained can be concluded that the test of essential oil activity of betel leaves, basil leaves citronella leaves and citrus leaves and there combination have activity as insect repellent to Aedes aegypti mosquito for 6 hours.

\section{REFERENCES}

Christaki, E., Bonos, E., Giannenas, I., and Paneri, P.F., (2012). Aromatic Plants as a Source of Bioactive Compounds. Agriculture, Vol. 2, pp. 228-243

Debboun, M., Frances, S.P., and Strickman, D.A., (2015). Insect Repellent Handbook, 2nd Ed. Boca Raton: CRC Press.

DEPKES RI, (1979). Farmakope Indonesia Edisi Ketiga. Jakarta: Departemen Kesehatan RI.

Ekowati, D., Abid, A. N., Merari, J., (2013). Uji Aktivitas Minyak Atsiri Kulit Buah Jeruk Nipis (Citrus aurantifolia, Swingle) dalam Sediaan Lotion sebagai Repelan terhadap Nyamuk Aedes aegypti. Jurnal Biomedika, Vol. 06, No. 01.

Fajarini, D.A., dan Murrukmihadi, M., (2015). Uji Aktivitas Repelan Minyak Atsiri Daun Kemangi Ocimum basilicum (L.) f. Citratum Back) terhadap Nyamuk Aedes aegypti dalam Sediaan Lotion dan Uji Sifat Fisik Lotion. Trad. Med. J., Vol. 20(2), p. 96 - 102.

Guenther, E., (1987). Minyak Atsiri Jilid 1. Jakarta: Penerbit Universitas Indonesia. 
Istianah, M.A., and Ameliana, U.W.S., (2013). Efektivitas Biolarvasida Minyak Daun Jeruk Purut (Citrus hystrix) Terhadap Larva Instar III Nyamuk Aedes aegypti. Jurnal Kedokteran.

Kabera, J. N., Semana, E., Mussa, A. R and He, X., (2014). Plant Secondary Metabolites: Biosynthesis, Classification, Function and Pharmacological Properties. Journal of Pharmacy and Pharmacology, $2: 377-392$.

Kalita, B., Bora, S., and Sharma, A.K., (2013). Plant Essential Oils as Mosquito Repellent-A Review. Int. J. Res. Dev. Pharm. L. Sci. Vol. 3, No.1, pp. 741-747.

Katsambas, A., Lotti, T., Dessinioti, and C., D'Erme, A.M., (2015). European Handbook of Dermatological Treatments, 3th Ed. Berlin Heidelberg: Springer-Verlag.

Mahesh, P., and Chandrashekar, K., (2010). Mosquito Repellent Activity of Piper betel Linn. IJPLS, 1(6):313-315.

Maia, M.F., and Moore, S.J., (2011). Plant-based Insect Repellents: A Review of Their Efficacy, Development and Testing. Malar J., 10 (Suppl 1): S11.

Medikanto, B. R., Setyaningrum, E., (2013). Pengaruh Ekstrak Daun Legundi (Vitex trifolia L.) sebagai Repellent terhadap Nyamuk Aedes aegypti. Medical Journal of Lampung University, Volume 2 No 4 Februari 2013.

Mohottalage, S., Tabacchi, R., and Guerin, P.M., (2007). Components from Sri Lankan Piper betle Leaf Oil and Their Analogues Showing Toxicity Against the Housefly, Musca domestica. Flavour Fragr. J., 22, pp. 130-138.

Novalny, D., (2006). Pengaruh Ukuran Rajangan Daun dan Lama Penyulingan terhadap Rendemen dan Karakteristik Minyak Sirih (Piper betle L.). Bogor: Skripsi Program Sarjana IPB.

Nurhidayati, L., Desmiaty, Y., dan Mariani, S., (2012). Penetapan Kadar Eugenol dalam Minyak Atsiri dari Daun Sirih Merah (Piper cf fragile Benth.) dan Sirih Hijau (Piper betle) secara Kromatografi Gas. Cimahi: Seminar Nasional POKJANAS TOI XLII.

Rani, N., Wany, A., Vidyarthi, A.S., and Pandey, D.M., (2013). Study of Citronella leaf based herbal mosquito repellents using natural binders. Current Research in Microbiology and Biotechnology, Vol. 1, No. 3 (2013): 98-103.

Rekha, V.P.B., Kollipara, M., Gupta, B.R.S.S.S., Bharath, Y., and Pulicherla, K.K., (2014). A Review on Piper betle: Nature's Promising Medicinal Reservoir. American Journal of Ethnomedicine, Vol. 1, No. 5, 276-289.

Sastrohamidjojo, H., (2004). Kimia Minyak Atsiri. Yogyakarta: Gadjah Mada University Press (Anggota IKAPI).

Singh, D.,( 2014). Advances in Plant Biopesticides. Springer.

Tiwari, R. and Rana, C. S., (2015.) Plant Secondary Metabolites: A Review. International Journal of Engineering Research and General Science, Vol. 3, Issue 5

Tutik, D. P., Wahyuningsih, D., dan Fibriawati, N., (2010). Potensi Minyak Atsiri Kemangi dan Selasih sebagai Insect Ovipositing Repellent. Yogyakarta: Prosiding Seminar Nasional, Kontribusi Penelitian Dosen pada Revitalisasi Pertanian. Akademi Pertanian Yogyakarta, pp. 117-128.

Yuliarto, F. T., Khasanah, L. U., Anandito, R. B. K., (2012). Pengaruh Ukuran Bahan dan Metode Destilasi (Destilasi Air dan Destilasi Uap-Air) terhadap Kualitas Minyak Atsiri Kulit Kayu Manis (Cinnamomum burmannii). Jurnal Teknosains Pangan, Vol 1 No 1, p 12 - 23.

Wink, M., (2015). Modes of Action of Herbal Medicines and Plant Secondary Metabolites. Medicines, 2: 251-286 